\section{Greens oppose EPO plant}

\section{Munich}

OPPONENTS of genetic engineering from all over West Germany descended on the sleepy university town of Marburg last week to present a wide assortment of objections to a biotechnology plant for the production of the drug erythropoietin (EPO), which stimulates the creation of red blood cells in patients with kidney failure. In protesting against the plant, the opponents, led by the Green party, took advantage of a long-awaited opportunity: the first public licensing hearing in West German history for a gene-technology facility.

The licensing battle is an important test case for the future of industrial genetic engineering in West Germany. It could affect the 'framework law' for genetic engineering scheduled to be debated in parliament this fall. Other companies, including BASF $\mathrm{AG}$, are facing similar hearings in the next few months.

Both Behringwerke AG, which owns the plant, and the Greens expect the plant to be licensed despite the protest, and both expect a legal battle to follow. Behringwerke had applied to produce EPO in 1988 but submitted its application again after the law was changed to require a public hearing (see Nature 335, 199; 1988).

The licensing authority, which in this case is the regional government in Giessen, announced that it would rule on the application by the end of the year.

The Greens made an impressive showing at the hearing both in the volume and the content of their objections. There were nearly 2,000 written objections to the plant, many of which concerned the moral and ethical aspects of genetic engineering. But the Greens also raised technical objections that they claim Behringwerke had not been expecting.

For example, Regine Kollek of the Greens objected to the genetic vector used to transform mouse cells in culture and induce them to produce EPO. Kollek claimed that bovine papilloma virus 1 (BPV 1) is present in the cells in its entirety and that a single virus particle might cause harm to humans.

The Greens called for data on the genetic lineage of the mouse whose cells will be used for the cultures, in order to determine if the mouse carries viruses such as mouse mammary tumour virus (MMTV) that might increase the chances of recombination, with unforeseen genetic consequences.

Behringwerke responded that these charges are "scientifically irrelevant." For instance, Behringwerke denied that BPV 1 might appear in either the cells or the EPO itself. The company reported that the cell line in question has been used for

\section{Tokyo}

JAPANESE scientists hope to be the first to launch into orbit a satellite that can be linked to radiotelescopes on Earth to form a huge VLBI (very-long-baseline interferometry) network.

The VLBI Space Observatory Programme (VSOP) is being promoted by the Institute of Space and Astronautical Science (ISAS) in collaboration with researchers at the Nobeyama Radio Observatory of the National Astronomical Observatory and the Communication Research Laboratory, and was described at an international symposium in Tokyo at the end of last month. A recent decision by the Space Activities Commission to allow ISAS to build a larger solid fuel rocket (Nature 340, 8; 6 June 1989) has given a boost to VSOP, and preliminary funds for the project are included in the budget request for fiscal year 1990 just submitted by the Ministry of Education, Science and Culture (see page 92).

ISAS hopes to launch the VLBI satellite in early 1995. Its closest competitor was the European Space Agency (ESA)'s VLBI- satellite QUASAT. But ESA cancelled the project last year, leaving only Japan and the Soviet Union in the field, given that the United States has no plans for a VLBI satellite. The Soviet Union hopes to launch the Radioastron satellite in 1993 but Japanese scientists involved in VSOP think it is likely to be delayed.

The orbit of the VSOP satellite will have an apogee of $20,000 \mathrm{~km}$ and, when linked to radiotelescopes on Earth, will create a VLBI radiotelescope network with an effective diameter of $30,000 \mathrm{~km}-$ about three times the size and resolution of the biggest networks on Earth.
15 years without any evidence that endogenous retroviruses might be activated. But Behringwerke spokesman Wolfgang Faust said that the company expects to be asked for further documentation before a license is granted.

Marina Steindor, spokeswoman for the national Green party working group on gene technology, said the Greens made "great progress" at the hearing. Steindor said that public hearings should be a part of the licensing procedure for all biotechnology products.

In the proposed genetic engineering law, hearings would not be required for some production processes involving "harmless" strains.

The issues raised at the licensing hearing would sound familiar to those United States companies that first won permis- sion a decade ago or more to use genetic engineering for the production of drugs. But whereas the US debate came to be dominated by pragmatism, the German debate is marked by the opposition's almost religious adherence to the belief that all genetic engineering is hazardous and should not be allowed anywhere. Those concerned seem prepared to resort to any legal means to prevent companies from using this technology.

Behringwerke must leap more hurdles, for instance in obtaining a licence to sell EPO, even if the production licence is granted.

But despite all the difficulties, Behringwerke is not considering pulling out of West Germany. "We're a Marburg company," said Faust. "We've invested DM10 million [\$6 million] in the plant already. It would be senseless if we could not use it."

Steven Dickman

\title{
Japan plans a space VLBI
}

Radiotelescopes in the United States, Europe, Australia and Japan will participate in the programme. Discussions are under way with the Soviet Union according to Haruto Hirosawa, professor of remote-sensing engineering at ISAS. The structure of the central cores of quasars, active galactic nuclei and other compact radio sources will be studied and their relative positions and motions obtained with "unsurpassed accuracy" ISAS scientists say.

Under an earlier plan, the antenna of the satellite would have been limited to a diameter of 5 metres because of the small lift capacity of ISAS's biggest rocket, the MU-3SII. But the Space Activities Commission in June approved a proposal by ISAS to develop a solid-fuel rocket with three times the power of the MU-3SII which has allowed ISAS scientists to double the planned size of the antenna to 10 metres, says Hirosawa.

Various ingenious designs for the antenna were presented by companies at the symposium last month, including an inflatable antenna design put forward by Kawasaki Heavy Industries and a mesh antenna design by Toshiba. But ISAS has decided to give the contract to Mitsubishi Electric Corporation for a tension truss design. NEC will handle the rest of the satellite and communications.

The total cost of the satellite is not yet certain but, according to Jun Nishimura, director general of ISAS, it will not be much more than that of previous ISAS satellites. They typically cost a few tens of millions of dollars, while the larger rocket for the launch will cost about $¥ 5,000$ million (\$35 million)

David Swinbanks 